\title{
Analisis Keterampilan Menulis Karangan Narasi Tema Aktivitasku Saat Libur Sekolah Siswa Kelas V SD Negeri 2 Pandansari Tahun Ajaran 2018/2019
}

\author{
Mauludia Pangastuti ${ }^{1 *}$, dan Nourma Oktaviarini ${ }^{2}$ \\ STKIP PGRI TULUNGAGUNG \\ E-mail: Maulp0803@gmail.com, \\ nourma@stkippgritulungagung.ac.id
}

\begin{abstract}
Abstrak
Analisis keterampilan menulis karangan narasi tema aktivitasku saat libur sekolah siswa kelas V SD Negeri 2 Pandansari tahun ajaran 2018/2019. Tujuan dalam penelitian ini adalah menganalisis keterampilan menulis karangan siswa dengan tema kativitasku saat libur sekolah. Jenis penelitian ini yaitu kulitatif, data yang diperoleh dalam penelitian ini yaitu berupa deskriptif tentang keterampilan menulis karangan narasi siswa.. Subjek dalam peneitian ini yaitu siswa kelas $\mathrm{V}$ yang terdiri dari 10 siswa. Instrument yang digunakan dalam penelitian ini yaitu wawancar, lembar tes dan dokumentasi. Berdsarkan hasil menulis karangagn narasi siswa kelas $\mathrm{V}$ menunjukkan angka 209 dengan prosentase 65\% dalam kategori cukup. Berdasarkan hasil menulis karangan narasi siswa dengan kategori cukup maka dapat disimpulkan siswa hendaknya lebih berlatih lagi dalam menulis dengan baik.
\end{abstract}

Kata kunci: karangan narasi, keterampilan menulis

\section{PENDAHULUAN}

Keterampilan menulis adalah kemampuan menuangkan buah pikiran ke dalam bahasa tulis melalui kalimat-kalimat yang dirangkai secara utuh, lengkap, dan jelas (Byrne yang dikutip oleh Slamet Hal 106). Tulisan yang baik memerlukan tujuan yang jelas, agar isi dari tulisan tersebut dapat tersampaikan kepada pembaca, tahapan menulis yaitu melakukan persiapan, pengembangan isi karangan, selain itu diperlukan refisi agar penulisan baik. Hasil observasi awal pada tanggal 25 Februari 2019 lalu di sana dalam menulis karangan sudah cukup baik, hanya saja siswa ada yang masih saja menulis tidak menggunakan tanda baca seperti titik (.), koma (,), tanda tanya (?), siswa juga dalam menulis huruf pertama setelah tanda titik (.) tidak menggunakan huruf kapital. Menulis karangan narasi merupakan kompetensi menulis yang sudah ada dan dimulai dari Sekolah Dasar, Karangan narasi merupakan suatu bentuk karangan yang sasaran utamanya adalah tindak tanduk yang dijalin dan dirangkai menjadi sebuah peristiwa yang terjadi dalam satu kesatuan waktu (Keraf, 2007, hal 136).

Menulis karangan narasi merupakan kompetensi menulis yang sudah ada dan dimulai dari Sekolah Dasar. Siswa dapat mengungkapkan ide, gagasan dan perasaan kepada orang lain melalui menulis karangan narasi. Kemampuan menulis tidak bisa langsung dikuasi tanpa adanya latihan dan praktik yang dilakukan secara terus menerus hingga siswa merasa lebih mudah dalam menulis karangan narasi. Dalam penilaian keterampilan menulis karangan narasi menggunakan pedoman, yang bertujuan untuk memudahkan dalam melakukan penilaian hasil menulis siswa.

\section{METODOLOGI PENELITIAN}

Penelitian ini menggunakan penelitian dekskriptif kualitatif sebagai acuan proses dalam pelaksanaan penelitian di lapangan, karena dengan jenis pendekatan deskriptif kualitatif akan dihasilkan data-data yang berupa kata-kata. Menurut Moleong (2005, hal 6), penelitian kualitatif adalah penelitian yang bermaksud untuk memahami fenomena tentang apa yang dialami oleh subjek 
penelitian misalnya perilaku, persepsi, motivasi, tindakan, dll secara holistik, dan dengan cara deskripsi dalam bentuk kata-kata dan bahasa, pada suatu konteks khusus yang alamiah dan dengan memanfaatkan berbagai metode alamiah.

Penelitian ini adalah untuk mengetahui keterampilan menulis karangan narasi siswa kelas V SD Negeri 2 Pandansari yang terdiri dari 10 siswa 5 siswa laki-laki dan 5 siswa perempuan. Sebagai upaya untuk memperoleh kebenaran atau mencari jawaban dari permasalahan yang ada, maka peneliti menggunakan jenis kualitatif. Alasan peneliti mengambil penelitian ini karena di kelas $\mathrm{V}$ sebagai subjek penelitian karena di kelas $V$ siswa masih diajarkan untuk membuat karangan narasi dan kendala yang biasanya di hadapi oleh siswa yaitu pada pemilihan kosakata, ejaan, isi , dan lainlain. Berikut ini adalah kisi-kisi wawancara dan kisi-kisi lembar tes siswa yang dikutip dari Giordano (1984) dalam Jumaris 2014.

Tabel 1 Kisi-Kisi Soal Tes Siswa

\begin{tabular}{|c|c|c|c|c|}
\hline Unsur yang & Keterangan & $\mathbf{N}$ & & Jum \\
\hline Dinilai & & o Soal & lah & \\
\hline Ketepatan & Siswa mampu menulis & 1 & & 1 \\
\hline Pernyatan & $\begin{array}{l}\text { karangan narasi dengan jelas dan } \\
\text { mudah dipahami }\end{array}$ & & & \\
\hline Susunan kata & $\begin{array}{l}\text { Siswa mampu menyusun kata- } \\
\text { kata dengan tepat }\end{array}$ & 1 & & 1 \\
\hline Paragraf & $\begin{array}{l}\text { Siswa dapat membuat isi dari } \\
\text { paragraf satu dengan paragraph } \\
\text { lainnya berkaitan }\end{array}$ & 1 & & 1 \\
\hline Kalimat & $\begin{array}{l}\text { Siswa mampu menulis kalimat } \\
\text { dengan kompleks dan pemotongan } \\
\text { kalimat tepat }\end{array}$ & 1 & & 1 \\
\hline $\begin{array}{ll} & \text { Penggunaan } \\
\text { Kata } & \end{array}$ & \begin{tabular}{lcc}
\multicolumn{1}{c}{ Siswa } & mampu & menulis \\
karangan & narasi & dengan \\
menggunaan kata-kata yang & sesuai
\end{tabular} & 1 & & 1 \\
\hline $\begin{array}{l}\text { Penggunaan } \\
\text { Huruf Besar }\end{array}$ & $\begin{array}{l}\text { Siswa mampu menulis } \\
\text { menggunakan huruf besar sesuai } \\
\text { dengan penggunaan pada kata } \\
\text { benda, kata sifat, huruf pertama } \\
\text { dalam kalimat, huruf pertama dalam } \\
\text { kutipan dan judul tulisan }\end{array}$ & 1 & & 1 \\
\hline Tanda Baca & $\begin{array}{l}\text { Siswa mamapu menggunakan } \\
\text { tanda baca sesuai dengan } \\
\text { kebutuhuan pada kalimat yang } \\
\text { dipakai. }\end{array}$ & 1 & & 1 \\
\hline Ejaan & $\begin{array}{c}\text { Siswa mampu menulis } \\
\text { karangan dengan ejaan yang tepat }\end{array}$ & 1 & & 1 \\
\hline
\end{tabular}

\section{HASIL DAN PEMBAHASAN}

Lembar tes siswa dilakukan untuk mengetahui keterampilan siswa dalam menulis karangan narasi dengan tema yang telah ditentukan, Peneliti akan memaparkan deskripsi data penelitian. Data yang diperoleh dari hasil penelitian lalu dideskripsikan baik secara umum maupun tiap-tiap indikator secara khusus. Data keterampilan menulis siswa didapat dari lembar tes siswa, setiap siswa diminta menulis karangan narasi pada lembar kerja yang telah dibagikan. Lembar tes siswa berisi 8 aspek indikator. Langkah pertama dalam melakukan tes siswa yaitu menyiapkan kisi-kisi tes. Langkah selanjutnya yaitu menyusun lembar tes siswa yang dilengkapi dengan lembar penilaian tes siswa. Peneliti melakukan tes di kelas V SD Negeri 2 Pandansari yang terdapat 10 siswa, peneliti mengambil sampel 10 siswa itu sendiri. Adapun hasil tes dan lembar tes siswa keterampilan menulis 
siswa dijabarkan dalam tabel dibawah ini :

Tabel 2 Hasil Tes Keterampilan Menulis Karangan Narasi

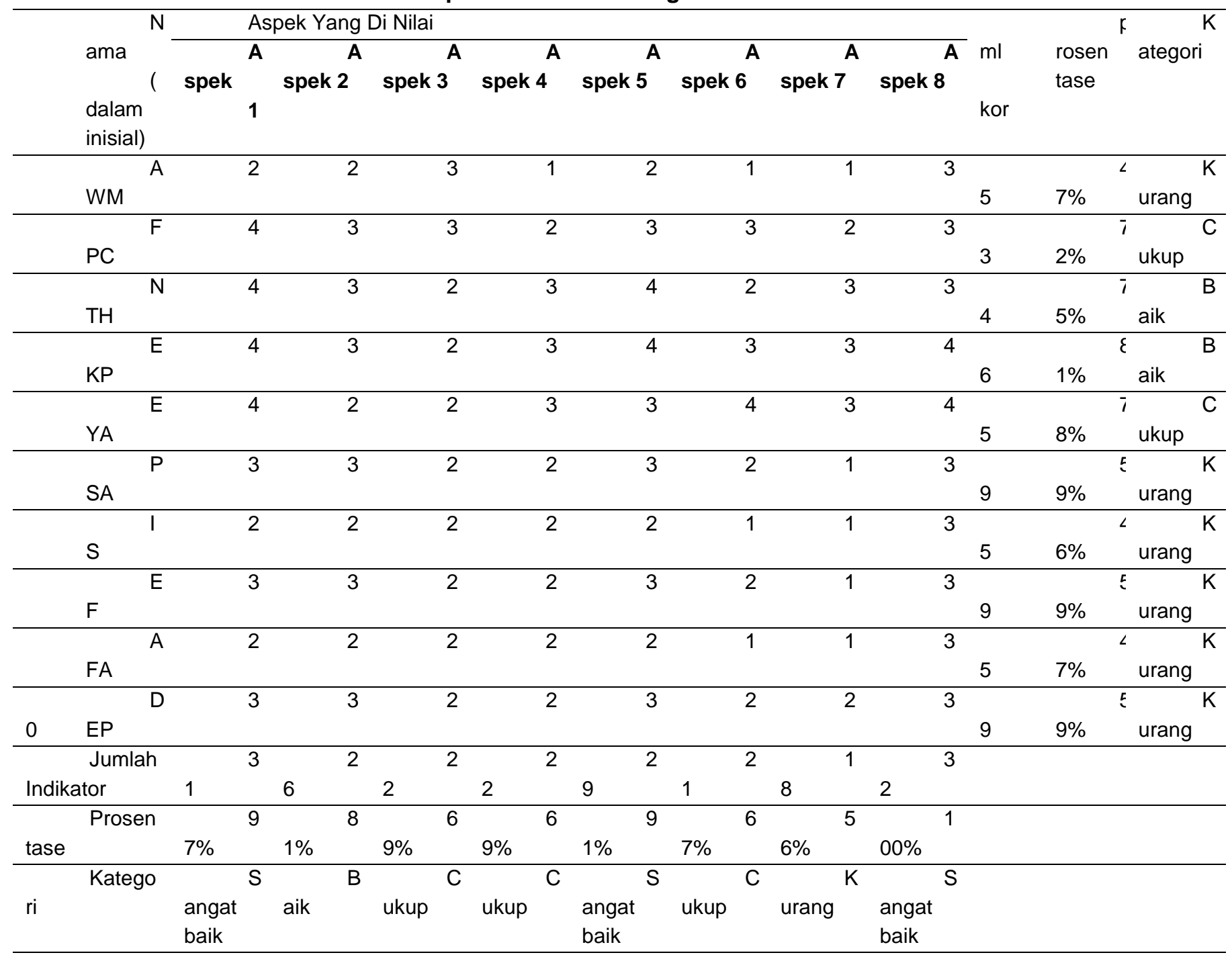

Jumlah Skor Keterampilan Menulis

09

Prosentase Keterampilan Menulis

$5 \% \quad$ ukup

Berdasarkan tabel 2 lembar penilaian keterampilan menulis siswa dapat diketahui bahwa pada aspek 1 (ketepatan pernyataan) diperoleh hasil skor menunjukkan angka 31 dengan prosentase 97\% dari 10 siswa yang tergolong dalam kategori sangat baik. Pada aspek 2 (susunan kata) diperoleh hasil skor menunjukkan angka 26 dengan prosentase $81 \%$ dari 10 siswa yang tergolong dalam kategori baik. Pada aspek 3 (paragraf) diperoleh hasil skor menunjukkan angka 22 dengan prosentase $69 \%$ dari 10 siswa yang tergolong dalam kategori baik. Pada aspek 4 (kalimat) diperoleh hasil skor menunjukkan angka 22 dengan prosentase 69\% dari 10 siswa yang tergolong dalam kategori cukup. Pada aspek 5 (penggunaan kata) diperoleh hasil skor menunjukkan angka 29 dengan prosentase $91 \%$ dari 10 siswa yangtergolong dalam kategori sangat baik. Pada aspek 6 (penggunaan huruf besar) diperoleh hasil skor menunjukkan angka 21 dengan prosentase $67 \%$ dari 10 siswa yang tergolong dalam kategori cukup. Pada aspek 7 (tanda baca) diperoleh hasil skor menunjukkan angka 18 dengan prosentase $56 \%$ dari 10 siswa yang tergolong dalam kategori kurang. Pada aspek 8 (ejaan) diperoleh hasil skor menunjukkan angka 32 dengan prosentase $100 \%$ dari 10 siswa yang tergolong dalam kategori sangat baik. 
Berdasarkan hasil penelitian mengenai keterampilan menulis karangan narasi tema aktivitasku saat libur sekolah siswa kelas V SD Negeri 2 Pandansari dengan menggunakan metode pembelajaran tematik terpadu dapat disimpulkan bahwa kemampuan keterampilan menulis karangan narasi siswa dalam aspek indikator yang ditentukan menunjukkan capaian prosentase sebesar $65 \%$ dari keseluruhan indikator. Dimana angka tersebut termasuk dalam kategori ketiga dengan rentan $60 \%-75 \%$, sehingga termasuk dalam kategori "cukup".

\section{PENUTUP}

Berdasarkan hasil penelitian yang telah disajikan pada bab sebelumnya maka dapat disimpulkan bahwa hasil menulis karangan narasi siswa kelas $\mathrm{V}$ mendapat total skor 209 dengan prosentase $65 \%$ dalam kategori cukup. Dengan rincian indikator ketepatan pernyataan dengan prosentase $97 \%$. Indikator susunan kata dengan prosentase $81 \%$. Indikator paragraf dengan prosentase $69 \%$. Indikator kalimat dengan prosentase $69 \%$. Indikator penggunaan kata dengan prosentase $91 \%$. Indikator penggunaan huruf besar dengan prosentase $67 \%$. Indikator ejaan dengan prosentase $100 \%$.

Sarannya adalah bagi siswa hendaknya bisa lebih meningkatkan keterampilan menulis dengan baik kosakata dan pengungkapan isi karangan ditingkatkan lagi. Bagi guru hendaknya mampu lebih sering melatih siswa dalam menulis karangan narasi dengan menggunakan gambar seri yang lebih menarik bagi siswa. Bagi sekolah sebagai tolok ukur bagaimana upaya untuk meningkatkan keterampilan menulis karangan narasi siswa dan sekolah dapat menyediakan sarana dan prasarana yang kondusif agar keterampilan menulis siswa semakin baik.

\section{UCAPAN TERIMAKASIH}

Terimakasih kepada Ketua STKIP PGRI Tulungagung, Kepada Wakil Ketua Bidang Akademik, Kepada Ketua Program Studi Pendidikan Guru Sekolah Dasar, Kepada Bapak/lbu dosen pembimbing, SD N 2 Pandansari.

\section{DAFTAR PUSTAKA}

Dalman.(2016). Keterampilan Menulis.Jakarta : Rajawali Pers Jamaris, Martini. (2015). Kesulitan Belajar. Jakarta : Ghalia Indonesia Sugiono, (2015).Metodologi Penelitian Kualitatif, Kuantitatif dan R\&D. Bandung : Alfabeta S. R. Ahmad., dkk. (2015). Mudah Menguasai Bahasa Indonesia. Bandung: CV Yrama Widya. Yulianti, Retno. (2016). Peningkatan Keterampilan Menulis Karangan Narasi Menggunakan Media Pop-Up Book Pada Siswa Kelas IV SD Negeri 2 Kedunglegok Kecamatan Kemangkon Kabupaten Purbalingga Tahun Ajaran 2015/2016.Yogyakarta : Universitas Negeri Yogyakarta. 